Marianna Papastephanou

University of Cyprus

\title{
PEACE AND WILDERNESS
}

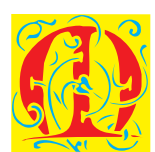

ost postmodern philosophy tends to set peace discourse aside. The present paper takes issue with this tendency and explores some reasons for such a neglect of rethinking peace. Relying on a longer work, ${ }^{1}$ the paper exclusively focuses on one aspect of wilderness and peace that may be indicated with the metaphorization of peace as homeless. Thus, the paper presupposes the ground that the longer work has covered. Such ground comprised mappings of some of the multiple political operations of the 'metaphoricity' of wilderness. It also comprised illustrations of how such metaphoricity heightens our awareness of the world of today: a world where peace is absent and various excuses and alibis for this absence play a pacifying role. Contemporary reality was there sketched as a constructed wilderness, unsuitable and unlikely qua peace's dwelling place. The figurative substratum of that critique was formed through brief references to Aristophanes' comedy Peace.

This paper condenses the main thesis of the longer essay, which can be summed up as follows: the naturalization and normalization of the homelessness of peace that may be extrapolated from some postmodern discourses should be interrogated. Some discourses within the broad designation 'postmodern' make room for viewing the lack of abode as ontologically more appropriate for peace. Thought through, such discourses imply that all search for a home for peace amounts to seeking a stable, conflict-free and orderly world and ostensibly reflects a by now obsolete metaphysics of presence. Granted, these discourses offer us the opportunity to realize the need for a nuanced notion of conflict. And they show us the inescapability and significance of some conflicts for life - an issue neglected in a modernity obsessed with order. But,

1 M. Papastephanou, "Where Does True Peace Dwell?” in: Pedagogy, Politics and Philosophy of Peace, ed. C. Borg and M. Grech, London: Bloomsbury, 2017. 
by also failing to discern between detrimental conflict and desirable controversy, these postmodern discourses ironically run the risk of metaphysically, though unwittingly, naturalizing and normalizing the human-made wilderness that blocks true peace.

\section{Wilderness}

In Cornelius Tacitus' Agricola, the Caledonian leader Calgacus urged his people to war against the Roman Empire to secure their freedom. The first paragraph of his speech ended with the famous dictum: 'Theft, slaughter and rape, the liars call Empire; they create a wilderness and call it peace'. Ever since, 'they create a wilderness and call it peace' has become widely-known and widely-used. The implicit tension between peace and its façade has often been encountered in various political writings throughout the centuries. Yet, after Immanuel Kant's monumental essay 'Perpetual Peace', too few works deal head-on with peace within the continental philosophical persuasion. ${ }^{2}$ Especially postmodern continental thought seems to have conceded all philosophical engagement with the notion of peace to modern liberal accounts.

Granting peace a possible 'home' depends on the onto-anthropological association of peace and wilderness. In Calgacus' dictum, solitudo, wilderness, often translated as 'solitude', 'desolation' or 'desert', is not natural but constructed, since 'they create' it, that is, it is human made. The subject creating it is in plural; an aggressive, imperialist 'they' committing atrocities and cloaking them with the euphemism 'peace'. But, beyond the dictum, in many cases, the 'they' having the upper hand cannot be clearly distinguished from a subjected, docile and impotent 'we'. Nor can it be personalized and neatly demarcated from complex, capillary and 'productive' forms of power that modern and postmodern subjects fail to resist. Nevertheless, even if the creation of wilderness burdens a specific agential collective subject, the perpetuation of wilderness also burdens passive recipients. The latter tolerate and often condone, instead of combating, power operations that effect wilderness - a wilderness that, against hopes for perpetual peace, becomes eternal pacification.

Resistance to the constructed wilderness (and, thus, the hope of peace becoming a resident in the human world) presupposes, in my view, faith in the possibility

2 I. Kant, "Toward Perpetual Peace," in: Political Writings, ed. H. Reiss, trans. H. B. Nisbet, second edition, Cambridge: Cambridge University Press, 1991. 
of doubleness of peace - a doubleness that comprises a true and ideal peace as well as a pseudo-peaceful state of affairs. Discerning a wilderness that is only nominally peace inserts a critical distance between a façade of peaceful coexistence and a true or genuine irenic life. If the former is constructed rather than natural to humans, the possibilities of overcoming it for the sake of hosting the latter in our world increase.

The distinction between true peace and pseudo-peace - whose possible deconstructibility never annuls the necessity of drawing it - is compatible with, and illuminates, another distinction, that of negative and positive peace. Whereas positive peace involves notions such as justice and equality, negative peace is simply the absence of direct violence or war. ${ }^{3}$ It is a state of affairs where 'no active and organized military violence is taking place'. The negative sense is 'the most common understanding of peace, not only in the context of international politics', but also 'in the context of the peace and war debate. ${ }^{4}$ Pax romana is an example of negative peace sliding into a façade of harmony, a state of affairs where the absence of violence through legal arrangements, military forces and social repression secures a pseudo-peace. The critical distance that Calgacus inserted between the created wilderness and the name 'peace' indicates the necessary critical contrast between a facile negative peace, on the one hand, and a positive one of genuine transcendence of the constructed wilderness, on the other hand.

Yet, we should also consider whether wilderness is inherently connected to peace or to war because, if wilderness is an inescapable ontological state, then, logically, the distinction between genuine and pseudo-peace (and the political prospect it opens) collapses. Whereas in Calgacus' dictum wilderness is created, in much modern philosophy (and less explicitly in postmodern philosophy) the wilderness obstructing peace has been thought as natural, and war has been seen as inherent to the condition humaine. Thomas Hobbes, for instance, whose over-riding concern had been a kind of peace, had naturalized war as a pre-contractual state of affairs - a 'state of nature where, without law and order, life is nasty, brutish and short'. ${ }^{5}$ As a natural state of war against all, an 'anarchy of equals' naturally inclined to fight and always in danger of mutual extinction, wilderness represented for many moderns the dystopian, though original, hu-

3 V. Bartolucci and G. Gallo, "Beyond Interdisciplinarity in Peace Studies: The Role of System Thinking” (2008), 7, 8. The article can be found here: http://pages.di.unipi.it/gallo/ Papers/Interdisciplinarity\&Peace.pdf

4 Ibidem, 8.

5 J.D. Marshall, "Thomas Hobbes: education and obligation in the Commonwealth," Journal of Philosophy of Education, 14, 2, 1980, 194, 199. 
man condition that reflected their onto-anthropological self-understanding qua egoistic and belligerent beings. Such beings can avoid and mitigate their natural condition and inclinations (the natural wilderness) only through a pact. ${ }^{6}$ As a contractual state of a hierarchy of appeased, 'safe' and tamed egoists, wilderness (this time in Calgacus' sense of a state that passes for peace) represented the limit to utopia of modern imagination, the only attainable best possible world. For a naturally tarnished human being is unable of true and genuine peace.

Especially from modernity onwards, war rather than peace was viewed as the true and natural human condition, one that could only be mitigated contractually. A natural state of war against all has been a strong spatial metaphor, raising 'natural' obstacles to peace or naturalizing the socio-political failures to construct a permanent residence for peace. In a wilderness conceived as natural or as framed by natural parameters, true peace cannot find a home. The peace that suits such spatiality can only be 'pseudo' or, at best, a brittle balance or a dim semblance. ${ }^{7}$

But natural wilderness was, at times, also conceived as an idyllic and happy state, a long surpassed golden age, 'an age before strife and suffering..$^{8}$ Often, this wilderness utopianized and romanticized the 'primitive' spatialities that Westerners encountered outside their ever receding borders and construed as pre-contractual. But more often, it offered the means for what can be called 'inverted

6 Though John Locke's version of the pact differed from Hobbes', it shared some of the Hobbesian naturalization and anthropological accommodation of strife at the pre-contractual level. And it slid into the constructed wilderness that Calgacus chastised by practically attenuating or disregarding claims to justice and equality of women, the poor and the 'uncivilized'.

7 The social contract tradition from Hobbes and Locke down to much current liberalism legitimizes itself via the intro-state wilderness that it presupposes as symbolic yet natural and aspires to surpass. Immanuel Kant's (1991) perpetual peace and vision of international right/cosmopolitan law extends the social contract to inter-state relations to lead the world beyond its wilderness and turn it into peace's stable, everlasting and proper home. Kant is rather ambivalent about the naturalness of the wilderness of the pre-cosmopolitan state of affairs: at times it seems more constructed than natural, but, at times, Kant attributes it to anthropological parameters such as the 'unsocial sociability of men', the 'foul stain of our species' and the 'radical' qua rooted cruelty inherent in humanity. For a critical account on Kant's position, see: M. Papastephanou, "Utopian Education and Anti-utopian Anthropology," International Education Studies, 6, 2013, 2, 22-33.

8 C. Zammit, "Responding to the Call of Peace: in memory of a future that might have been," in: Lorenzo Milani's Culture of Peace, ed. C. Borg and M. Grech, New York: Palgrave Macmillan 2014, 77-90. 
utopianization': the utopia of 'primitive' simplicity was wholly grafted on foreign lands, though not affirmatively, as in most utopianizing tactics, but rather negatively and dismissively. The remote space offered no ground for a nostalgic longing for return to humanity's original home. Rather, its Golden Age utopianization opened it up as a primitive space, a hitherto empty though fertile land for western inscription. ${ }^{9}$

Through such operations, philosophy often reflected, abetted, crystallised or sleepwalked society's way to violence. ${ }^{10}$ Some injustices tended to occur mostly elsewhere inflicted by the philosophers' dwelling places upon other spatialities, on supposed 'wildernesses' in 'need' of the Western man's taming and civilizing industriousness. The colonial example of terra nullius provides yet another sense of wilderness, that of the foreign, un-cultivated natural spatiality whose supposed non-utilization by its inhabitants legitimizes conquest and pax romana effects.

9 A case in point is the logic of terra nullius (empty, uncultivated land) in Locke. Locke saw the colony of Virginia as in a 'state of nature', which 'state of nature' justified the colonial enterprise and exploitation. Virtue, for Locke, is then associated with the kind of productive labour that replenishes earth and justifies peoples' earning of titles to lands and goods. Conversely, people inhabiting land 'that they either cannot or will not develop' may be treated as 'aggressors against those who can and would develop that land'. Wayne Glausser gives a detailed account of how such assumptions framed Locke's endorsement of slave trade and participation in the institutions of slavery and his exceptions to people's right to defend their country when it is threatened by conquest. Such an exception is the following: 'if a native population should "resist conquest of their waste land, they become aggressors in war", and the developers may justly kill them and enslave captives'. Eager to make his mark on the tabula rasa of American waste land, Locke considered wasteland a 'wilderness' awaiting 'the virtuous energy of European developers, who may find themselves killing, enslaving and philosophizing in the interests of development'. (W. Glausser, "Three approaches to Locke and the slave trade," Journal of the History of Ideas, 1990, 200-215.

${ }^{10}$ In a context of powerful empires (often mis-recognized as nation-states) that continued to form the setting of western states of exception throughout (post-) modernity, various injustices were bequeathed to later generations as impossible and intractable legacies. For instance, such a case of western states of exception was the reality effected by the fact that a colonial metropolis would issue the Atlantic Charter by which the principle of peoples' self-determination was affirmed, only to come some years later to exempt some colonies from the exercise of that principle in order to keep them under its control for geopolitical purposes. Creating exceptions to self-determination rendered the western state in control of the colony exceptional, a case where the relativization of principles is supposedly appropriate. The colonial spaces that suffered such an exception (denying their freedom) were burdened with the impossible situation that this very exception created and are still struggling with the concomitant political 'legacy'. 


\section{Peace's home and homelessness}

If the human world-as-wilderness is constructed rather than natural, then the causes of war must be sought neither in a supposedly human condition nor in characterological, psychologistic and moralist explanations. Amartya Sen's response to such issues is that 'an enlightened attitude to war and peace must go beyond the immediate' to seek underlying, 'deeper' causes. In looking for such causes 'the economics of deprivation and inequity has a very plausible claim to attention. ${ }^{\text {'1 }}$ To accommodate peace human beings should reconsider and reshape their world and undo its wilderness, at least that which is effected by needless cruelty rather than by unavoidable misfortune. To illustrate through literary/narrative imagination: in Aristophanes' Peace, the dwelling place of a deified though exiled peace is sought beyond the then current state of affairs. In the play, war is not inevitable and its state is human-made and de-naturalized. ${ }^{12}$

And in the here and now? Can a poly-centric capitalist world be peace's dwelling place? No, because, as Walter Mignolo succinctly puts it, such a world is not 'a de-colonial world'. The poly-centric, capitalist world does not dispense with 'the colonial matrix of power and the colonial and imperial differences regulating the field of forces in the modern/colonial world. ${ }^{13}$ A de-colonial cosmopolitanism shall be 'the becoming of a pluri-versal world order built upon and dwelling on the global borders of modernity/coloniality. ${ }^{\prime 14}$ Here, global borders evoke contact zones where different people meet. In most contemporary postcolonial theory these zones are considered sites where the promise of better politics may materialize. The underlying faith in plurality that singles out the global border as the possible abode for peace invites, in my opinion, one of Iris Young's questions. Young doubted whether Europe has shown any signs of recognizing its past. We may adapt this to apply to powerful collectivities beyond Europe, those that are also typically designated as Western up to the global imaginary of the 'global city', the contact zone, the pluri-versal global border. 'Colonialism was not just a vicious process of

11 A. Sen, "Violence, identity and poverty," Journal of Peace Research, 45, 1, 2008, 5-15.

${ }_{12}$ M. Papastephanou, "Where Does True Peace Dwell?" in: Pedagogy, Politics and Philosophy of Peace, ed. C. Borg and M. Grech, London: Bloomsbury, 2017.

13 W. Mignolo, "Cosmopolitanism and the De-colonial Option," Studies in Philosophy and Education 29, 2010, 124.

${ }^{14}$ Ibidem, 117. 
modernization, but a system of slavery and labor exploitation'. What are the signs that European people and states (or the de-colonial 'cosmopolitans' of a pluri-versal global border) 'have responded to a call for accountability with gestures of contrition and reparation?'. ${ }^{15}$

Through our framework so far, let us ask the questions: what is our world, ${ }^{16}$ the hardly surprising world of today, the one supposed to host peace? From what genealogy has it emerged? Can peace dwell in a predatory world without justice, in a world of double standards and states of exceptions that compromise the universality of law, in a world of Realpolitik where acquisitive and power-hungry mentalities hold sway?

Our world, the unsurprising world of today, also contains peace education. Sharon Anne Cook gives a very rich and detailed account of how peace is understood in the theoretical context of peace education. ${ }^{17}$ Yet, radical critique of the existent, radical self-questioning and awareness of the need for radical redirection do not surface at all in that account. All the self-reflective turn to the real is exhausted in realizing (in the multiple senses of the word) its global possibilities of interconnectedness, as if oppression cannot occur when people are side by side. Thus, a 'domesticated' reflection bypasses the role that a deeper discontent with current realities and with the lip-service to discursively hegemonic ideals such as tolerance, diversity and respect should play.

Our world also hosts radical theoretical subversions of the search for peace's home or for a peaceful home. Global justice is often treated as easily deconstructible or as a residue of Kantian, obsessive visions of perpetual peace. Thus, deconstruction and deconstructibility sometimes become polemical tools for undermining the other's claims to justice, but never for questioning one's own claims to relativizing justice. In this way, deconstructive operations often contribute to the perpetuation rather than to undoing injustices. Yet, neither justice is so easily deconstructible nor is one's recourse to time-honoured mindsets of sophistry as unnoticeable as it so far seems.

15 I. M. Young, "De-Centering the Project of Global Democracy," in: Old Europe, New Europe, Core Europe, ed. D. Levy, M. Pensky and J. Torpey, Verso: London, 2005, 157.

${ }_{16}$ The "is" of this question should not be read in the metaphysical sense that it acquires in specialized idioms of metaphysics. It refers to the socio-political constructed reality that invites our critical attention. Such attention was usually described by Theodor Adorno and other Frankfurt School theorists as 'a critique of the existent'.

17 S. A. Cook, "Reflections of a Peace Educator: The Power and Challenges of Peace Education With Pre-Service Teachers," Curriculum Inquiry, 44, 4, 2014, 489-507. 
Can peace dwell in a world where even philosophy tends now to legitimize conflict indirectly by asserting that we live in an imperfect world where disorder may be celebrated as redemptive, where we are all refugees as the language that constructs us is never a true home, and that, by extension, true peace might be the refugee par excellence? ${ }^{18}$ I see such dangerous theoretical implications in Jacques Derrida's Monolingualism but, admittedly, to unpack and justify this claim the full length of another essay would be necessary. Hence, I state this as a relevant though as yet non-theorized claim. ${ }^{19}$

The issue about the limited human potentiality in an imperfect world underpins much postmodern discourse. It directs it not only to accepting the homelessness of peace but even to giving onto-anthropological permanence to such homelessness. Thinkers who have never experienced the true state of exile celebrate it figuratively. It will come as no surprise if they start to explore the space that is purportedly opened by the supposedly endemic homelessness of peace (notice the ironic and deliberately paradoxical use of 'endemic' here, a term that etymologically involves 'having a stable home'). They glorify the figure of the refugee and its rootless potentialities, unable as they are to distinguish the ontological space of the precariousness of articulated order (and homelessness/lack of permanent residence of meaning) from the political space of a people deprived of home through acts of violence. Deep down, a reason for this inability to discern nuance is, in my view, an unspoken though operative conception of the natural inevitability of conflict. Instead of de-naturalizing war and the constructed wilderness to which the operation of naturalization offers an alibi, much current theory surrenders the hope for peace. It treats peace as obsessive order. It sees it as a last vestige of the modern fascination with revolutionary optimism or of a longing for wholeness, harmony and consensus in a dissonant world that renders all this naïve and futile.

The underlying assumption of those who welcome this view may be that the post-modern debunking of grand narratives is a/the recipe for peace; that war and conflict are brought about by such narratives, particularly those spurred by modern optimism. Certainly, modern optimism is not

18 To acknowledge the importance of dissent without normalizing conflict I draw a distinction between conflict and controversy: a conflict-free world would not be a controversy-free world, so, a commitment to resolving conflicts does not necessarily affirms appeasement or an obsessive sense of order.

19 J. Derrida, Monolingualism of the Other, or, the Prosthesis of Origin, Stanford: Stanford University Press, 1998. 
only untenable within the confines of a constructed wilderness, as I have argued in the longer work, ${ }^{20}$ but it is even dangerous in its implicit, hegemonic assumptions for reasons that are well-known and we need not delve into them. But those who unquestioningly give in to the post-modern 'promise' of 'petits récits' fail to notice that, if thought through to its ultimate implications, the wholesale incrimination of order, consensus, perfectibility and utopia leads to a deconstruction of the very search for peace's 'home'. ${ }^{21}$ The glorification of the figure of the refugee as a general condition for all of us and, by implication, of notions such as peace may render the question about peace's 'home' expendable and thus declare peace a 'refugee' par excellence. Such are, in my view, the implications of Sharon Todd's book Toward an Imperfect Education. ${ }^{22}$ The book critiques the assumed goodness of humans that underwrites the idea of humanity and explores how antagonistic human interactions such as conflict and violence are a fundamental aspect of life in a pluralistic and imperfect world, thus giving ontological 'citizenship' to wilderness and making peace's 'residence rights' irrelevant.

The philosophical idioms that I have criticized render the very question about the dwelling of peace expendable, obsolete, meaningless, a residue of old metaphysics, an un-sophisticated longing for abode, rootedness and stability. If the authority of such approaches mainly derives from their academic currency then, perhaps, the answer to them might be a deliberate and thoughtful obsolescence. Critiquing such philosophical idioms as mostly new liberal self-exculpating tactics, we may realize that the state of refugee is not ontologically determined/determining for peace. It is rather a condition constructed by the constantly (re)created wilderness in which we live. So long as human beings continue to find 'naturalizing' or 'ontologizing' paltry excuses for the wilderness they create and perpetuate, true peace will remain an exile. Like Sophocles' Antigone, true peace is hypsi-polis (aspiring to the best imaginable polis) and for this reason it will remain a-polis (home-less) in our wild world of today.

${ }^{20}$ M. Papastephanou, “Where Does True Peace Dwell?”...

${ }^{21}$ As for the postmodern faith in the debunking of grand narratives, suffice it here to refer to the fact that Alain Badiou has already exposed the grand narrative character that this faith ironically has acquired and his vehement critique of some postmodern tenets.

A. Badiou, Manifesto for Philosophy, trans. N. Madarasz, Albany: State University of New York Press, 1999, 31.

22 S. Todd, Toward an Imperfect Education: Facing Humanity, Rethinking Cosmopolitanism, Boulder, CO: Paradigm Publishers, 2009. 
The causes of war along with the perpetuation (or exculpations) of injustices may range from material ones related to profit up to more symbolic ones related to naturalizing the created wilderness and taking it for-granted. Lack of attentive care to the contextual aspect of world problems and to their complexity proves that, even when intentions are good, an uneven or limited cultivation of intellectual and ethical virtues blocks the required nuance in understanding and critiquing various realities.

Perhaps the paradox of peace is that, in the world today, its cause may not be promoted by the irenic talk that follows the contours of the existent without changing it, like a caress. It may be promoted by the confrontational words that hammer the existent, by the cynic and sarcastic idiom that transfers polemos from the battlefield to the philosophical language game. 'Unveiling the world requires us to acknowledge the crimes against humanity - genocide, slavery, colonization, incarceration and impoverishment. ${ }^{23}$ In my view, it requires more than just acknowledging them. It requires radical redirection, more imaginative ways out of the current situation and more ability to go beyond established metonymies of atrocities. A true unveiling of the world also presupposes that we retrieve the non-thematized issue, the pending ethical debt, and the unresolved world problem. World-disclosure can use an idiom that destroys the lame excuses for the current situation, de-naturalizes alibis and de-beautifies a world that sees itself, despite indications to the opposite, as the best possible or as requiring facile solutions. Possibly, unveiling the world requires an acknowledgement of its wilderness as constructed and a dose of contemptus mundi, even an averted, horrified eye. ${ }^{24}$

\section{References}

Aristophanes' Peace, http://classics.mit.edu/Aristophanes/peace.html Badiou, A., Manifesto for Philosophy, trans. N. Madarasz, Albany: State University of New York Press, 1999.

${ }^{23}$ M. A. Darder, "Peace Education in a Culture of War," in: Lorenzo Milanis Culture of Peace, ed. C. Borg and M. Grech, New York: Palgrave Macmillan, 94, 204.

${ }^{24}$ Perhaps that was why, in Aristophanes' Peace, Trygaeus turned to the audience and dystopianized it by addressing it in a way that evokes an interplay of transcendent and immanent gaze: 'How small you were, to be sure, when seen from heaven! You had all the appearance too of being great rascals; but seen close, you look even worse'. See: http://classics. mit.edu/Aristophanes/peace.html 
Bartolucci, V. and G. Gallo, "Beyond Interdisciplinarity in Peace Studies: The Role of System Thinking,” 2008. http://pages.di.unipi.it/gallo/Papers/Interdisciplinarity\&Peace. pdf (2 February, 2016).

Cook, A. S., "Reflections of a Peace Educator: The Power and Challenges of Peace Education with Pre-Service Teachers," Curriculum Inquiry 44.4, 2014, 489-507.

Darder, M. A., "Peace Education in a Culture of War," Lorenzo Milani's Culture of Peace, C. Borg and M. Grech (eds.), New York: Palgrave Macmillan, 2014.

Derrida, J., Monolingualism of the Other, or, the Prosthesis of Origin, Stanford: Stanford University Press, 1998.

Glausser, W., "Three approaches to Locke and the slave trade," Journal of the History of Ideas, 1990, 200-215.

Kant, I., "Toward Perpetual Peace," Political Writings, H. Reiss, ed., trans. H. B. Nisbet, Cambridge: Cambridge University Press, 1991.

Marshall, J.D., "Thomas Hobbes: education and obligation in the Commonwealth," Journal of Philosophy of Education 14.2, 1980, 194-199.

Mignolo, W., "Cosmopolitanism and the De-colonial Option," Studies in Philosophy and Education 29, 2010, 111-127.

Papastephanou, M., "Where Does True Peace Dwell?", Pedagogy, Politics and Philosophy of Peace, ed. C. Borg and M. Grech, London: Bloomsbury, 2017.

Papastephanou, M., "Utopian Education and Anti-utopian Anthropology," International Education Studies 6, 2013, 2, 22-33.

Sen, A., "Violence, identity and poverty," Journal of Peace Research, 45.1, 2008, 5-15.

Todd, S., Toward an Imperfect Education: Facing Humanity, Rethinking Cosmopolitanism, Boulder: Paradigm Publishers, 2009.

Young, I., "De-Centering the Project of Global Democracy," Old Europe, New Europe, Core Europe, D. Levy, M. Pensky and J. Torpey (eds.), London: Verso, 2005.

Zammit, C., "Responding to the Call of Peace: in memory of a future that might have been," Lorenzo Milanis Culture of Peace, C. Borg and M. Grech (eds.), New York: Palgrave Macmillan, 2014, 77-90. 